\title{
Залежність рівня працездатності військовослужбовців від параметрів їх медичного обслуговування
}

\author{
Володимир Мірненко *1 А; Олег Шекера ${ }^{2}$ в; Сергій Пустовий ${ }^{3}$; \\ Петро Яблонський ${ }^{4}$; $;$ Микола Бутенко ${ }^{5}$; ; Олександр П'явчук ${ }^{6 \text { D }}$ \\ А Департамент військової освіти і науки Міністерства оборони України, пр-кт Повітрофлотський 28, м. Київ, 03049, Україна \\ в Національна медична академія післядипломної освіти імені П.Л. Шупіка, вул. Дорогожицька, 9, м. Київ, 04112, Україна \\ “ТОВ “Котрис", вул. Петра Нестерова, 3, м. Київ, 03680, Україна \\ D Національний університет оборони України імені Івана Черняховського, пр-кт Повітрофлотський 28, м. Київ, 03049, Україна
}

Received: August 5, 2021 | Revised: August 23, 2021 | Accepted: August 31, 2021

DOI: $10.33445 /$ sds.2021.11.4.5

\begin{abstract}
Анотація
У статті встановлена залежність коефіцієнта працездатності військовослужбовців від рівня якості постановки діагнозу в медико-санітарній частині, звернення за медичною допомогою, тривалості лікування, інтенсивності помилкових звернень за медичною допомогою при певних значеннях решти параметрів математичної моделі. Результати досліджень отримані при умові, що функція розподілу часу між захворюваннями військовослужбовців має експоненціальний характер, а процеси математичного моделювання описуються напівмарковським випадковим процесом.
\end{abstract}

Ключові слова: коефіцієнт працездатності, тривалість лікування, рівень діагностики, періодичність проведення диспансерних оглядів, математична модель.

\section{Постановка проблеми}

У попередніх дослідженнях для системи медичного обслуговування було побудовано математичну модель їі функціонування та була встановлена аналітична залежність коефіцієнта працездатності військовослужбовців від параметрів моделі [1, 2, 3].

Разом 3 тим, організаторів системи медичного обслуговування військовослужбовців цікавить кількісна залежність запропонованого коефіцієнта працездатності від основних параметрів системи медичного обслуговування, що дасть можливість прогнозувати рівень працездатності як для одного військовослужбовця так, і для цілих структурних підрозділів військовослужбовців.

На відміну від математичної моделі медичного обслуговування населення, де використовувався дифузійно-немонотонний закон розподілу часу між захворюваннями людини, у даній статті використовується експоненціальний закон розподілу цього часу. Саме такий закон розподілу часу притаманний для військовослужбовців, які в цілому мають досить високий рівень здоров'я.

\section{Аналіз останніх досліджень та публікацій}

В роботі [1] отримана аналітична залежність коефіцієнта працездатності службовців від параметрів військовомедичного обслуговування, а саме: рівня захворюваності, періодичності проведення диспансерних оглядів, звернень за медичною допомогою у

\footnotetext{
1 * Corresponding author: д.т.н., професор, Заслужений працівник освіти України, директор Департаменту, е-mail: mirnenkovi@gmail.com, ORCID: 0000-0002-7484-1035

2 д.мед.н., професор, e-mail: director_IFM_NMAPO@ukr.net, ORCID: 0000-0002-5430-3379

${ }^{3}$ к.т.н., e-mail: psa@kotris.ua, ORCID: 0000-0002-6081-1193

${ }^{4}$ к.т.н., доцент, професор кафедри, e-mail: teyka1943@gmail.com, ORCID: 0000-0003-2651-4299

5 провідний науковий співробітник Центру воєнно-стратегічних досліджень, e-mail: mirnenkovi@gmail.com, ORCID: 0000-0002-5623-1866

${ }^{6}$ ад'юнкт, e-mail: pjawa0905@gmail.com ORCID: 0000-0002-5623-1866
} 
разі захворювання, якості діагностування у медико-санітарній частині та шпиталі, тривалості лікування, інтенсивності помилкових звернень за медичною допомогою. Там же встановлена залежність коефіцієнта працездатності від періодичності проведення диспансерних оглядів при різних рівнях захворюваності.

Наявна стаття $є$ продовженням попередньої статті [1]. Такі результати отримані 3 використанням математичного моделювання.

\section{Постановка завдання}

Основною метою статті $€$ встановлення кількісної залежності коефіцієнта працездатності від періодичності проведення медичних обстежень, інтенсивності захворювань, імовірності своєчасного звернення військовослужбовця за медичною допомогою, якості постановки діагнозу як в медико-санітарній частині, так і в шпиталі, тривалості лікування,

інтенсивності хибних звернень за медичною допомогою.

Вказані параметри змінювались у широкому діапазоні, що дає можливість організаторам медичного обслуговування встановити рівень працездатності при певній комбінації параметрів моделі.

значні, то така модель не може бути прийнята, тому що критерієм істини $€$ практика.

Вважається, що модель може бути прийнято, якщо розбіжності між результатами моделювання і практичними результатами не перевищує 20\%. Для досягнення більшої точності потрібно розробляти більш складну модель.

На четвертому етапі у разі необхідності математична модель коригується.

В останні роки внаслідок широкого впровадження обчислювальної техніки і програмного забезпечення методи математичного моделювання набули широкого розвитку і стали використовуватися у повсякденній практиці.

У медичних дослідженнях методи кореляційних досліджень почали використовувати для обробки медичних даних з 80-х років XIX століття. Відтоді методи статистики розвивались під впливом біометричних досліджень.

Дослідження залежності коефіцієнта працездатності від рівня якості постановки діагнозу в медико-санітарній частині.

Суттєвим показником якості медичного обслуговування військовослужбовців $€$ якість постановки діагнозу у медико-санітарній частині. Своєчасна і якісна постановка діагнозу дозволяє на ранніх стадіях виявляти захворювання та розпочинати лікування. Тому 
рівень постановки діагнозу необхідно обов'язково враховувати при побудові математичної моделі. Організаторам медичного обслуговування важливо знати наскільки підвищиться якість діагностики при проведенні певних заходів та як кількісно вплине рівень діагностики на рівень працездатності людини.

За критерій працездатності будемо використовувати коефіцієнт працездатності у вигляді [3].

$$
K_{\Pi P}=\frac{\sum_{i=1}^{n} \pi_{i}(T) \cdot \omega_{i}(T)}{\sum_{i=1}^{n} \pi_{i}(T) \cdot \mu_{i}(T)}
$$

де $\pi_{i}(T) \quad$ - частота потрапляння марковського ланцюга до стану $h_{\mathrm{i}}$;
$\omega_{i}(T)$ - середній час перебування військовослужбовця у працездатному стані $h_{\mathrm{i}}$;

$\mu_{i}(T)$ - математичне очікування тривалості одного кроку $\xi(t)$ при переході зі стану $h_{\mathrm{i},} \quad i=$ $\overline{1,7}$ до нового стану $h_{\mathrm{j}}, j=\overline{1,7}$.

Розрахунок залежності коефіцієнта працездатності від $\pi_{i}(T), \quad \omega_{i}(T)$ і $\mu_{i}(T)$ докладно описаний у роботі [1].

На рис. 1 та 2 показана залежність коефіцієнта працездатності (Кпр) від якості постановки діагнозу $\left(d_{\mathrm{Hг}}^{*}\right)$ в медико-санітарній частині при різних значеннях інтенсивності захворювань військовослужбовців $\left(\lambda_{0}\right)$ при періодичності проведення диспансерного огляду $T=12$ міс.(мал.1) і $T=24$ міс (мал. 2).

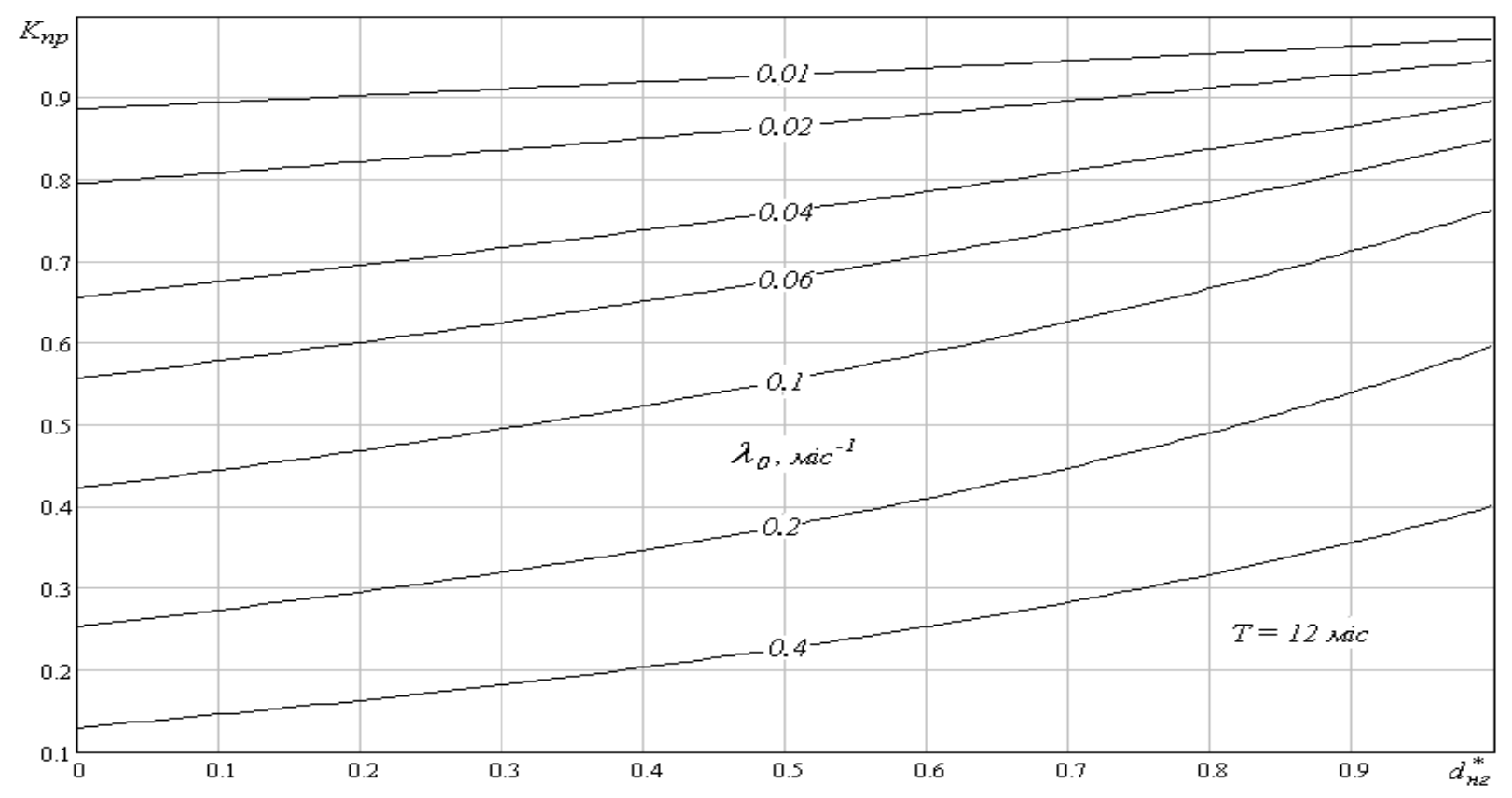

Рис. 1 - Залежність коефіцієнта працездатності $\left(K_{\text {пр }}\right)$ від якості постановки діагнозу $\left(d_{\mathrm{Hг}}^{*}\right)$ в медико-санітарній частині при різних значеннях інтенсивності захворювань

військовослужбовців $\left(\lambda_{0}\right)$ при періодичності проведення диспансерного огляду $T=12$ міс.

Постійні значення параметрів моделі, при яких побудовані на рис. 1 та рис. 2 залежності

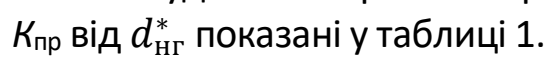

3 наведених графіків на рис.1 та рис.2 стає зрозуміло, що підвищення якості постановки діагнозу в медико-санітарній частині суттєво впливає на К пр особливо при високому рівні захворювань. Так з рис. 1 видно, що при збільшенні якості постановки діагнозу з 0 до 1

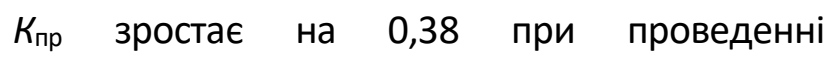

диспансерних оглядів через $T=12$ міс при $\lambda_{0}=$ 0,4 захворювань на місяць. Якщо рівень захворювань складає $\lambda_{0}=0,02$ захворювань на місяць, то збільшення якості постановки

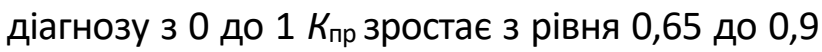
при $T=12$ міс. При проведенні диспансерних оглядів через $T=24$ місяця (рис. 2) зростання працездатності буде повільнішим за аналогічних умов. 


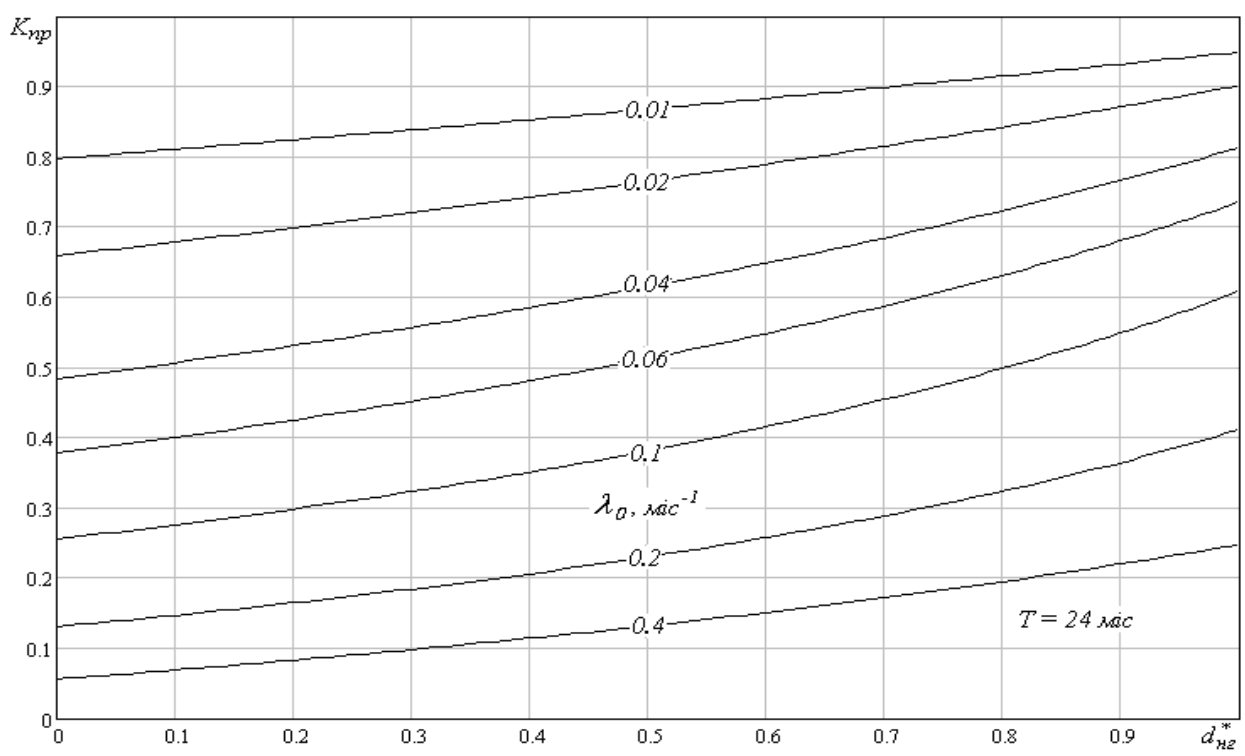

Рис. 2 - Залежність коефіцієнта працездатності $\left(K_{\text {пр }}\right)$ від якості постановки діагнозу $\left(d_{\mathrm{Hг}}^{*}\right)$ в медико-санітарній частині при різних значеннях інтенсивності захворювань військовослужбовців $\left(\lambda_{0}\right)$ при періодичності проведення диспансерного огляду $T=24$ міс.

Залежність коефіцієнта працездатності від звернень військовослужбовців за медичною допомогою.

Регулярні медичні обстеження військовослужбовців пов'язані з витратою певних коштів, тому деякі спеціалісти вважають за непотрібне їх проведення при умові, що вигідніше вкладати кошти не в організацію диспансерних оглядів, а в покращення доступності медичної допомоги, підвищення рівня санітарної культури. В країнах 3 високим рівнем медичного обслуговування при самих сприятливих умовах $є$ від 25 до 45 \% хворих людей, які не звертаються за медичною допомогою протягом року і більше $10 \%$ протягом 10 років. У зв'язку з цим представляє певний науковий i практичний інтерес визначення впливу ймовірності своєчасного звернення військовослужбовців за медичною допомогою на рівень їх працездатності. На рис.

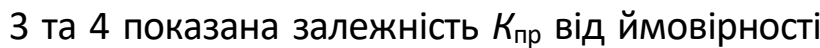
своєчасного звернення військовослужбовців за медичною допомогою при різних рівнях інтенсивності захворювань.

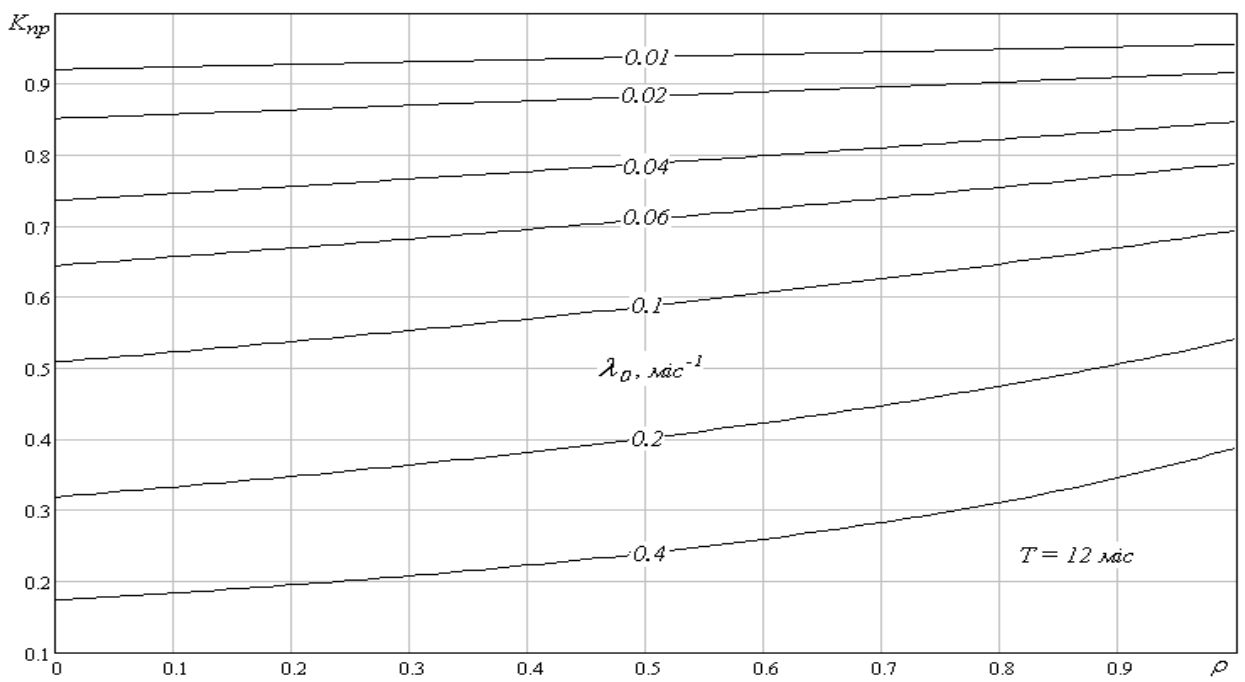

Рис. 3 - Залежність коефіцієнта працездатності $\left(K_{п р}\right)$ від ймовірності своєчасного звернення військовослужбовців за медичною допомогою при різних рівнях інтенсивності захворювань при періодичності проведення оглядів $T=12$ міс 


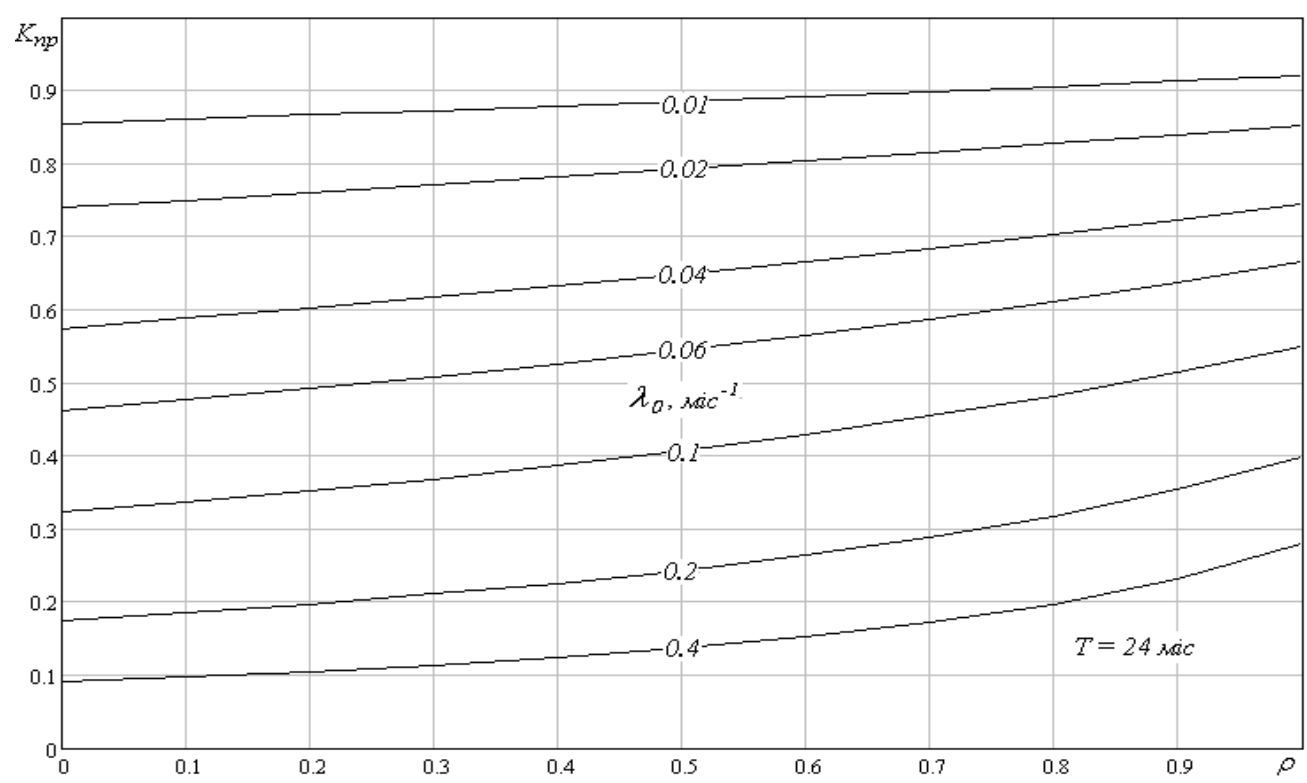

Рис. 4 - Залежність коефіцієнта працездатності $\left(K_{\text {пр }}\right)$ від ймовірності своєчасного звернення військовослужбовців за медичною допомогою при різних рівнях інтенсивності захворювань при періодичності проведення диспансерного огляду $T=24$ міс.

Графіки на рис. 3 і 4 побудовані при зміні ймовірності своєчасного звернення військовослужбовців за медичною допомогою з кроком 0,1 при зміні $\rho$ з 0 до 1. Параметром таких залежностей $€$ інтенсивність захворювань $\lambda_{0}$, що змінювалась з $\lambda_{0}=0,01$ до $\lambda_{0}=0,4$ захворювань на місяць. Ймовірність захворювань $\lambda_{0}=0,01$ захворювань на місяць означає одно захворювання військовослужбовця за майже вісім років. 3 наведених графіків стає зрозуміло, що своєчасне звернення військовослужбовця за медичною допомогою суттєво впливає на рівень їх працездатності. Така залежність $€$ яскраво вираженою при відносно високому рівні захворювань $\left(\lambda_{0}=0,2-0,4\right.$ захворювань на місяць). Це пояснюється тим, що у разі захворювання військовослужбовця своєчасне звернення за медичною допомогою призведе до своєчасного лікування i до скорішого одужання. Мірою зростання здоров'я $\left(\lambda_{0}=\right.$ 0,06-0,01 захворювань на місяць) така залежність стає менш помітною. При відносно високому рівні здоров'я лікарська допомога мало впливає на працездатність людини. 3 графіку на мал.3 видно, що при $\lambda_{0}=0,02$ захворювань на місяць підвищення ймовірності своєчасного звернення за медичною допомогою $3 \quad \rho=0,1$ до $\rho=1$ призводить до збільшення $K_{\text {пр }} 3$ рівня 0,85 до рівня 0,91. При $\lambda_{0}=0,4$ захворювань на місяць підвищення ймовірності своєчасного звернення за медичною допомогою з $\rho=$ 0,1 до $\rho=1$ призводить до збільшення $\mathrm{K}_{\text {пр }} 3$ рівня 0,19 до рівня 0,39(мал.4). Такі висновки $€$ справедливими при таких умовах, при яких вони побудовані і наведені на рис. 3 та 4. Слід відзначити, що при будь-якому рівні інтенсивності захворювань своєчасне звернення за медичною допомогою призводить до збільшення працездатності військовослужбовців. Можна зробити висновок про важливе значення медикоосвітньої роботи серед військовослужбовців про виховання у них почуття відповідальності за стан свого здоров'я. Своєчасне звернення військовослужбовців за медичною допомогою $€$ однією з ознак здорового способу житя.

Залежність коефіцієнта працездатності від тривалості лікування.

Тривалість лікування $€$ однією $з$ важливих характеристик системи медичного обслуговування. Вона залежить від багатьох чинників, серед яких до числа найбільш впливових слід віднести нозологічну форму захворювання і варіанти ії клінічного протікання, якість постановки діагнозу, наявність необхідних лікарських засобів, оснащення медичних установ сучасним лікувально-діагностичним обладнанням, 
рівень організаційної роботи та інше. захворювання, неточному діагнозі, відсутності Тривалість лікування в залежності від необхідних ліків тривалість лікування може нозологічної форми захворювання може бути значною. При зростанні часу на одужання змінюватися у широких межах. Для певного після хвороби працездатний стан зменшується. захворювання при сприятливих умовах Узв'язкуз цим представляє інтерес визначення (початкова стадія захворювання, точний кількісної залежності між тривалістю лікування діагноз, наявність необхідних ліків, правильне і рівнем працездатності при відомих лікування) тривалість лікування може бути характеристиках системи медичного невеликою. I навпаки, при запущеній формі обслуговування.

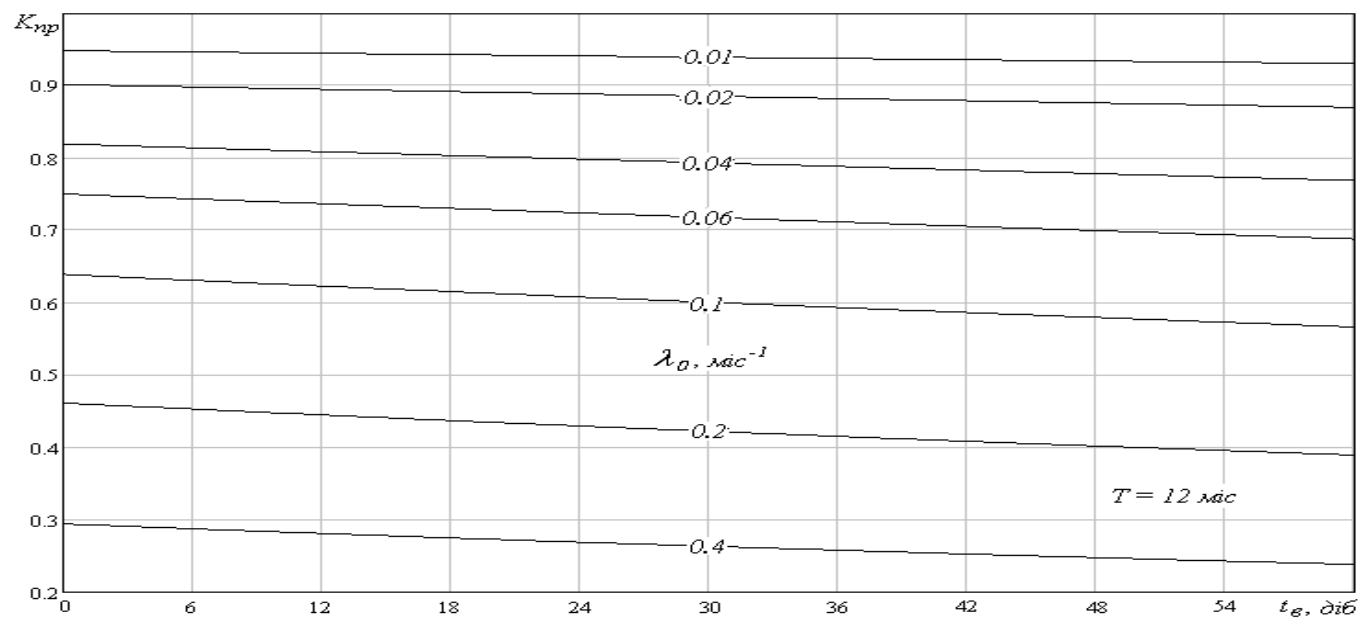

Рис. 5 - Кількісна залежність між тривалістю лікування і рівнем працездатності при відомих характеристиках системи медичного обслуговування при $T=12$ міс.

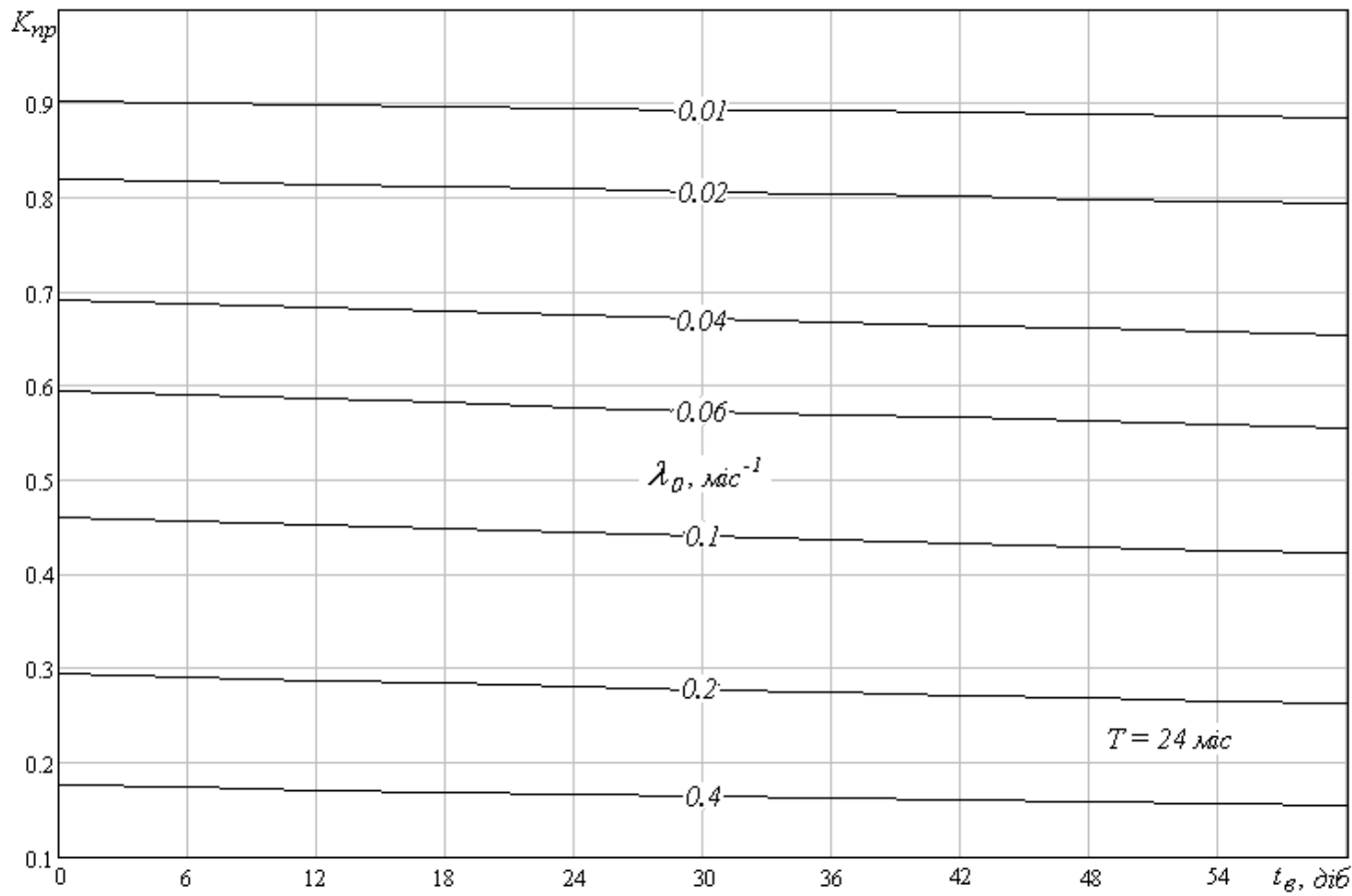

Рис. 6 - Кількісна залежність між тривалістю лікування і рівнем працездатності при відомих характеристиках системи медичного обслуговування при $T=24$ міс.

3 наведених на рис. 5 та 6 графіків стає зрозуміло, що при збільшенні тривалості лікування працездатність зменшується, а саме, тим більше, що більший рівень захворювання.
Так, наприклад, при збільшенні тривалості лікування від 0 до 60 діб при $\lambda_{0}=0,4$ захворювань на місяцьі при $T=12$ місяців працездатність зменшується з 0,29 до 0,24. Для 
рівня $\lambda_{0}=0,04$ захворювань на місяць за аналогічних умов зменшення рівня працездатності буде спадати з 0,81 до 0,78. Збільшення періоду проведення диспансерних оглядів до $T=24$ місяці призведе до зменшення рівня працездатності.

Залежність коефіцієнта працездатності від інтенсивності помилкового звернення за медичною допомогою.

Запропонована у роботі математична модель враховує помилки першого і другого роду, які зменшують працездатність військовослужбовців. Помилка першого роду враховує, що здоровий військовослужбовець може помилково звернутися за наданням медичної допомоги з різних причин: загроза ускладнення стану здоров'я, симуляція захворювання 3 метою уникнути відповідальності за скоєний вчинок, ухиляння від виконання службових обов'язків у певний момент, передчасне звільнення з армії тощо. У зв'язку з цим виникає необхідність встановити кількісний вплив інтенсивності помилкових звернень військовослужбовця за медичною допомогою на його працездатність. Тому представляє інтерес залежність $K_{\text {пр }}$ від періодичності проведення диспансерних оглядів при різній інтенсивності помилкових звернень за медичною допомогою для фіксованих значень рівня захворювань $\lambda_{0}=$
0,02 захворювань на місяць (рис. 7) і $\lambda_{0}=$ 0,04 захворювань на місяць (рис. 8). 3 наведених на рис. 7 та 8 залежностей стає зрозуміло, що існує оптимальна періодичність проведення диспансерних спостережень, при яких досягається найбільший рівень працездатності. Так на рис. 7 показана

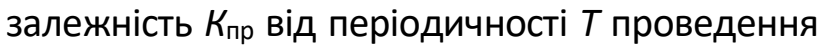
диспансерних оглядів для рівня захворювань $\lambda_{0}=0,02$ захворювань за місяць при інтенсивності помилкових звернень $\lambda=0,01$, $\lambda=0,02, \lambda=0,04, \lambda=0,08, \lambda=0,1$ i $\lambda=$ 0,4 захворювань за місяць.

3 наведених графіків видно, що зі збільшенням інтенсивності помилкових звернень зменшується працездатність, що $€$ цілком природнім. При зміні періодичності проведення медичних оглядів від $T=10$ до $T=40$ місяців спостерігається відносно несуттєвий вплив інтенсивності проведення помилкових звернень за медичною допомогою на рівень працездатності. Зі збільшенням інтервалу Т спостерігається збільшення дисперсії інтенсивностей $\lambda$ на рівень працездатності.

Збільшення рівня захворювань до $\lambda_{0}=0,04$ захворювань за місяць (рис. 8) призводить до зменшення рівня працездатності, але характер впливу інтенсивностей помилкових звернень за медичною допомогою зберігається.

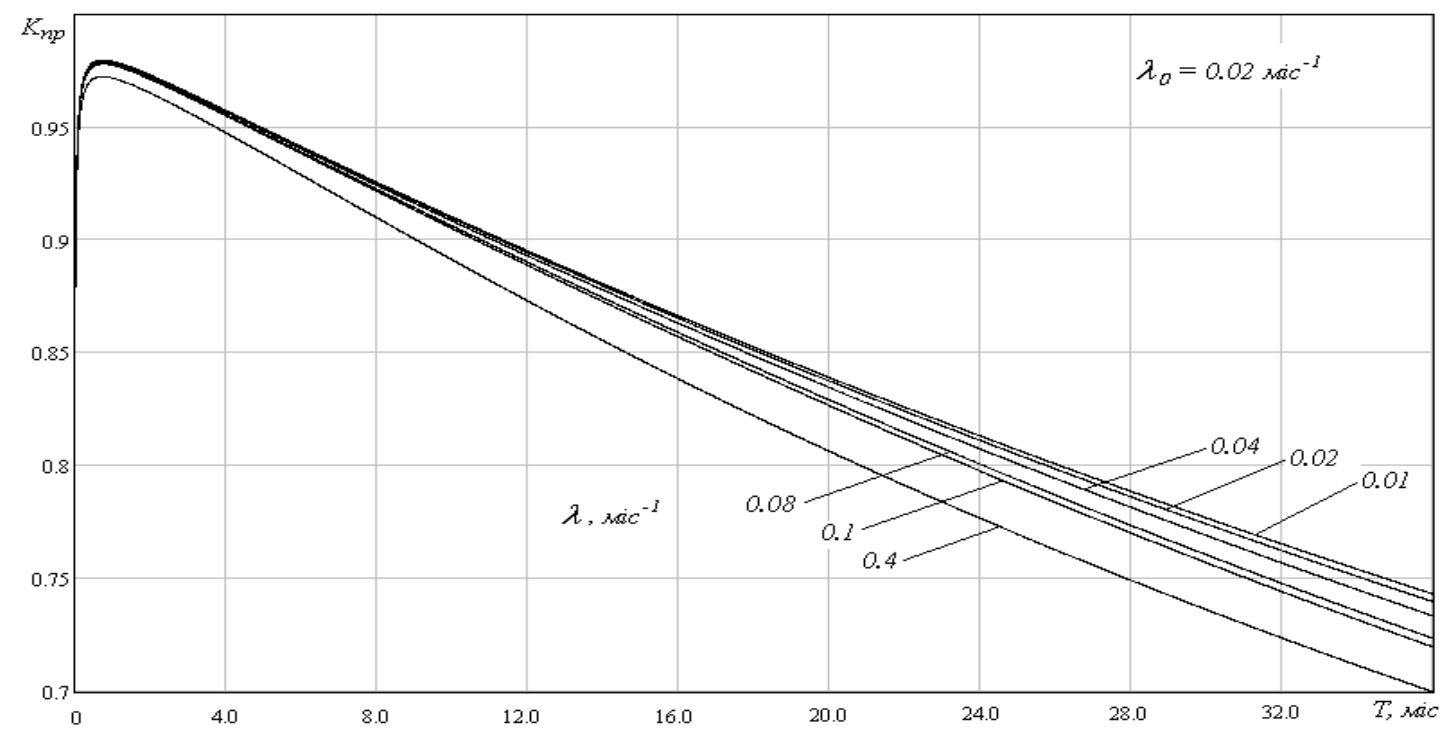

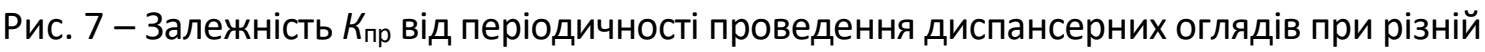
інтенсивності помилкових звернень за медичною допомогою для фіксованих значень рівня захворювань $\lambda_{0}=0,02$ захворювань на місяць 


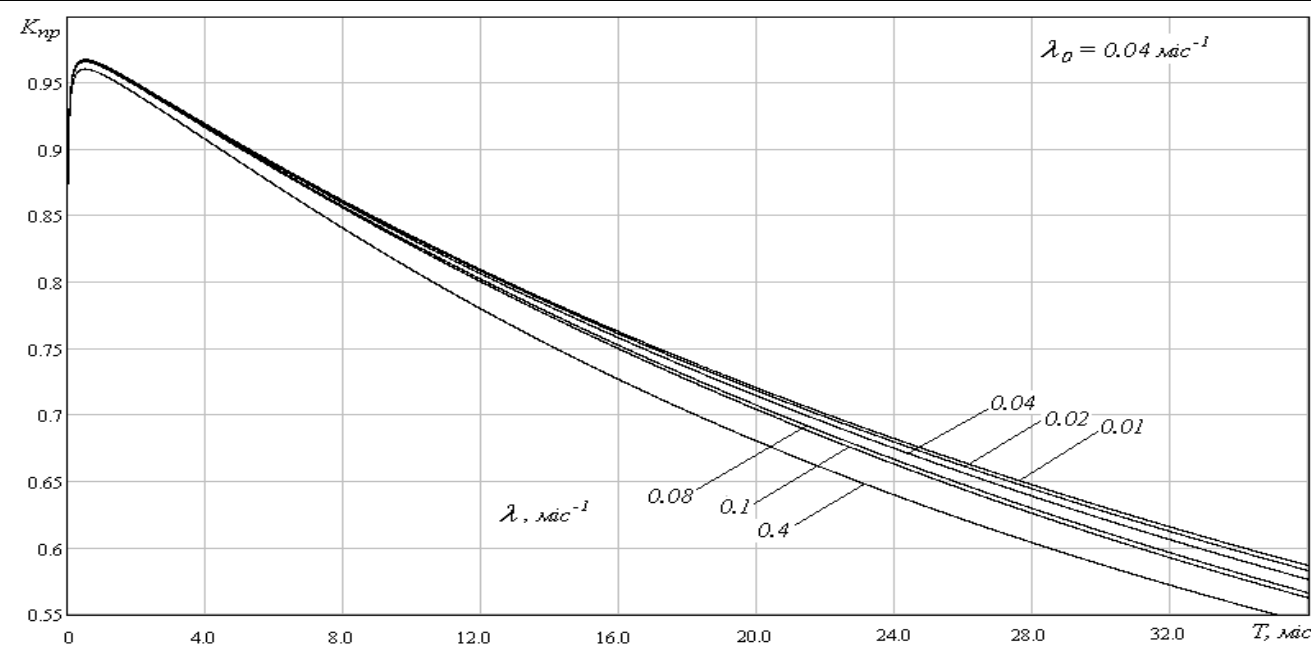

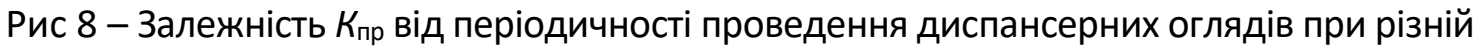
інтенсивності помилкових звернень за медичною допомогою для фіксованих значень рівня захворювань $\lambda_{0}=0,04$ захворювань на місяць

Таблиця 1 - Постійні значення параметрів моделі

\begin{tabular}{|c|c|c|}
\hline $\begin{array}{l}\text { № } \\
\text { puc }\end{array}$ & $\begin{array}{c}\text { Параметри, при яких побудовані залежності коефіцієнта } \\
\text { працездатності } \\
\end{array}$ & $\begin{array}{c}\text { Постійні параметри для } \\
\text { всіх рисунків }\end{array}$ \\
\hline \multirow[t]{2}{*}{1} & $\begin{array}{l}\mathrm{T}=12 \text { мiс., } \rho=0,7 ; d_{\mathrm{H \Gamma}}=0,85 ; \\
t_{\Pi}^{*}=0,0055 \text { мiс.; } \\
t_{\Pi}=0,0041 \text { мiс. } ; t_{\mathrm{B}}=0,328 \text { мiс. }\end{array}$ & \multirow[t]{12}{*}{$\begin{array}{l}\lambda=0,1 \lambda_{0} \\
\lambda_{\text {пр }}=0,1 \lambda_{0}\end{array}$} \\
\hline & змінна величина $d_{\mathrm{Hг}}^{*}$ & \\
\hline \multirow[t]{2}{*}{2} & $\begin{array}{l}\mathrm{T}=24 \text { мic., } \rho=0,7 ; d_{\mathrm{H \Gamma}}=0,85 ; \\
t_{\Pi}^{*}=0,0055 \text { мiс.; } \\
t_{\Pi}=0,0041 \text { мiс. ; } t_{\mathrm{B}}=0,328 \text { мiс. }\end{array}$ & \\
\hline & змінна величина $d_{\mathrm{Hг}}^{*}$ & \\
\hline \multirow[t]{2}{*}{3} & $\begin{array}{l}\mathrm{T}=12 \text { мiс., } ; d_{\mathrm{H \Gamma}}=0,85 ; t_{\Pi}^{*}=0,0055 \text { мiс.; } \\
t_{\Pi}=0,0041 \text { міс. } ; t_{\mathrm{B}}=0,328 \text { міс. } \quad d_{\mathrm{H \Gamma}}^{*}=0,7\end{array}$ & \\
\hline & змінна величина $\rho$ & \\
\hline \multirow[t]{2}{*}{4} & $\begin{array}{l}\mathrm{T}=24 \text { міс., } d_{\mathrm{H \Gamma}}=0,85 ; t_{\Pi}^{*}=0,0055 \text { міс.; } \\
t_{\Pi}=0,0041 \text { міс. ; } t_{\mathrm{B}}=0,328 \text { міс. } \quad d_{\mathrm{H \Gamma}}^{*}=0,7\end{array}$ & \\
\hline & змінна величина $\rho$ & \\
\hline \multirow[t]{2}{*}{5} & $\begin{array}{l}\mathrm{T}=12 \text { міс., } ; d_{\mathrm{H \Gamma}}=0,85 ; t_{\Pi}^{*}=0,0055 \text { міс.; } \\
t_{\Pi}=0,0041 \text { міс.; } t_{\mathrm{B}}=0,328 \text { міс. } d_{\mathrm{H \Gamma}}^{*}=0,7 ; \rho=0,7\end{array}$ & \\
\hline & змінна величина $t_{\mathrm{B}}$ & \\
\hline \multirow[t]{2}{*}{6} & $\begin{array}{l}\mathrm{T}=24 \text { мiс., } ; d_{\mathrm{H \Gamma}}=0,85 ; t_{\Pi}^{*}=0,0055 \text { міс.; } \\
t_{\Pi}=0,0041 \text { міс. } ; t_{\mathrm{B}}=0,328 \text { міс. } d_{\mathrm{H \Gamma}}^{*}=0,7 ; \rho=0,7\end{array}$ & \\
\hline & змінна величина $t_{\mathrm{B}}$ & \\
\hline \multirow[t]{2}{*}{7} & $\begin{array}{l}d_{\mathrm{H \Gamma}}=0,85 ; t_{\Pi}^{*}=0,0055 \text { міс.; } \rho=0,7 \\
t_{\Pi}=0,0041 \text { міс. ; } t_{\mathrm{B}}=0,328 \text { мiс. } \\
d_{\mathrm{H \Gamma}}^{*}=0,7 ; \lambda_{0}=0,02 \text { міс. }-1\end{array}$ & \multirow[t]{4}{*}{$\begin{array}{c}\lambda=0,01 ; 0,02 \\
0,04 ; 0,08 ; 0,1 ; 0,4\end{array}$} \\
\hline & змінні величини Т і $\lambda$ & \\
\hline \multirow[t]{2}{*}{8} & $\begin{array}{l}d_{\mathrm{H \Gamma}}=0,85 ; t_{\Pi}^{*}=0,0055 \text { міс.; } \rho=0,7 \\
t_{\Pi}=0,0041 \text { міс. ; } t_{\mathrm{B}}=0,328 \text { мiс. } \\
d_{\mathrm{H \Gamma}}^{*}=0,7 ; \lambda_{0}=0,04 \text { міс. }-1\end{array}$ & \\
\hline & змінні величини Ті $\lambda$ & \\
\hline
\end{tabular}




\section{Висновки}

Математична модель - це об'єкт, який замінює об'єкт - оригінал 3 метою його дослідження, зберігаючи деякі важливі для даного дослідження властивості оригіналу. Жодна, навіть найбільш довершена математична модель не може бути тотожною реальності. Адекватна модель означає, що вимоги точності, правильності, істинності моделі виконані лише тією мірою, яка необхідна для розв'язання поставленої задачі. Найкраща якість моделей досягається як компроміс між близькістю до оригіналу та простотою, що забезпечує зручність для використання.

В Збройних Силах України проводиться диспансеризація всього особового складу. Кінцевою метою диспансеризації $\epsilon$ забезпечення високого рівня здоров'я військовослужбовців та їх працездатності. Кількісним критерієм рівня працездатності $\epsilon$ коефіцієнт працездатності, який суттєво залежить від рівня захворювань, якості постановки діагнозу, періодичності проведення диспансеризації, ймовірності звернення за медичною допомогою, тривалості лікування, інтенсивності помилкового звернення військовослужбовця за медичною допомогою. В роботі проведено дослідження залежності коефіцієнта працездатності від вказаних параметрів. Нi одна 3 отриманих залежностей не протирічить здоровому глузду i добре відповідає фізичній суті. Прогнозований показник працездатності найбільш суттєво залежить від рівня захворювань та тривалості лікування. Для реальних рівнів захворювання коефіцієнт працездатності може бути збільшений шляхом підвищення якості діагностування від 2 до 10 \% в залежності від рівня захворювання.

Збільшення тривалості лікування понижує рівень працездатності. При будь-якій тривалості лікування для всіх рівнів захворювання більш високому рівню постановки діагнозу відповідає і більший коефіцієнт працездатності.

Виконані розрахунки показали важливе значення рівня санітарної культури військовослужбовців на їх працездатність. В залежності від рівня захворювання збільшення ймовірності своєчасного звернення за медичною допомогою на 0,1 може дати від 1,6 до 5 \% приросту коефіцієнта працездатності. Особливо виражене збільшення цього показника спостерігається для середніх та високих рівнів захворювання при підвищенні ймовірності своєчасного звернення за медичною допомогою з 0,7 та вище. Для високих рівнів захворювання коефіцієнт працездатності, що дорівнює 0,95, $\epsilon$ недосяжним для будь-яких рівнів звернення військовослужбовців за медичною допомогою, якості постановки та частоти проведення медичних оглядів. Це свідчить про обмежені можливості тільки медичних заходів. В таких умовах для підвищення працездатності військовослужбовців необхідно проведення комплексу соціальних заходів, що направлені на пониження захворювань.

Таким чином, у статті встановлено кількісну залежність коефіцієнта працездатності від параметрів системи медичного обслуговування, що дає можливість прогнозувати кількість здорових людей певної військової частини у будь-який момент часу. Проведене дослідження дало можливість визначити найбільш раціональні шляхи підвищення рівня працездатності за рахунок удосконалення планування діагностики, медико-профілактичної та санітарно-просвітницької роботи.

capacity coefficient of the servicemen from the parameters of the proposed model. Journal of Scientific Papers "Social 
Development and Security», 10(6), $19-28$.

DOI: 10.33445/sds.2020.10.6.3

2. Mirnenko, V., Yablonsky, P., Butenko, M., Lytvynko, S., \& Gutvert, R. (2019). Mathematical model for determining the effectiveness of medical examination of military personnel. Journal of Scientific Papers "Social Development and Security", 9(5), $143 \quad-\quad 157 . \quad$ DOI: 10.33445/sds.2019.9.5.10

3. Формалізована модель системи медичного населення. / Шекера О. Г., Яблонський П. М., Шекера О.О., Мельник Д.В., Кухарчук Х.М., Панасенко М. С. Здоров'я суспільства №3-4, 2016 року, С. $130-131$

4. Mirnenko, V., Yablonsky, P., Koskov, Y., \& Litvinko, S. (2017). The mathematical model of medical servicing of servicemen with the use semi-Markov stochastic process theory. Journal of Scientific Papers "Social Development and Security», 2(2), 12 - 24. DOI: 10.5281/zenodo.1117937

\title{
Зависимость уровня работоспособности военнослужащих от параметров их медицинского обслуживания
}

\author{
Владимир Мирненко *1А; Олег Шекера ${ }^{2 \text { B; }}$ Сергей Пустовой ${ }^{3 \mathrm{C}}$; \\ Петр яблонський ${ }^{4 D}$; Николай Бутенко ${ }^{5}$; Александр Пьявчук ${ }^{6 D}$ \\ *Corresponding author: ${ }^{1}$ д.т.н., профессор, Заслуженный работник образования Украины, директор Департамента, е-таі: \\ mirnenkovi@gmail.com, ORCID: 0000-0002-7484-1035 \\ 2 д.мед.н., профессор, e-mail: director_IFM_NMAPO@ukr.net ORCID: 0000-0002-5430-3379 \\ 3 к.T.H., e-mail: psa@kotris.ua, ORCID: 0000-0002-6081-1193 \\ ${ }^{4}$ к.т.н., доцент, профессор кафедры, e-mail: teyka1943@gmail.com ORCID: 0000-0003-2651-4299 \\ ${ }^{5}$ ведущий научный сотрудник Центра военно-стратегических исследований, e-mail: mirnenkovi@gmail.com ORCID: 0000-0002-5623-1866 \\ ${ }^{6}$ адъюнкт, e-mail: pjawa0905@gmail.com ORCID: 0000-0002-5623-1866 \\ А Департамент военного образования и науки Министерства обороны Украины, пр-кт Воздухофлотский, 28, г. Киев, 03049, Украина

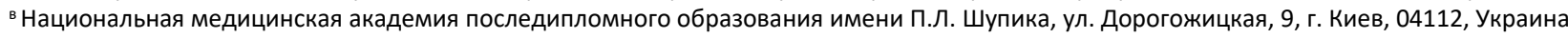 \\ сООО "КОТРИС", ул. Петра Нестерова, 3, г. Киев, 03680, Украина \\ D Национальный университет обороны Украины, пр-кт Воздухофлотский, 28, г. Киев, 03049, Украина
}

\begin{abstract}
Аннотация
В статье установлена зависимость коэффициента работоспособности военнослужащих от уровня качества постановки диагноза в медико-санитарной части, обращения за медицинской помощью, длительности лечения, интенсивности ложных обращений за медицинской помощью при определенных значениях остальных параметров математической модели. Результаты исследования получены при условии, что функция распределения времени между заболеваниями военнослужащих имеет экспоненциальной характер, а процессы математического моделирования описываются полумарковским случайным процессом.
\end{abstract}

Ключевые слова: коэффициент работоспособности, длительность лечения, уровень диагностики, периодичность проведения диспансерных осмотров, математическая модель.

\section{Dependence of the level of efficiency of servicemen on the parameters of their medical care}

\author{
Volodymyr Mirnenko *1 A; Oleg Shekera ${ }^{2}$ B; Sergey Pustovoy ${ }^{3}$ C; \\ Peter Yablonsky ${ }^{4}$; Mykola Butenko ${ }^{5 \mathrm{D}}$; Oleksandr Piavchuk ${ }^{6 \mathrm{D}}$
}




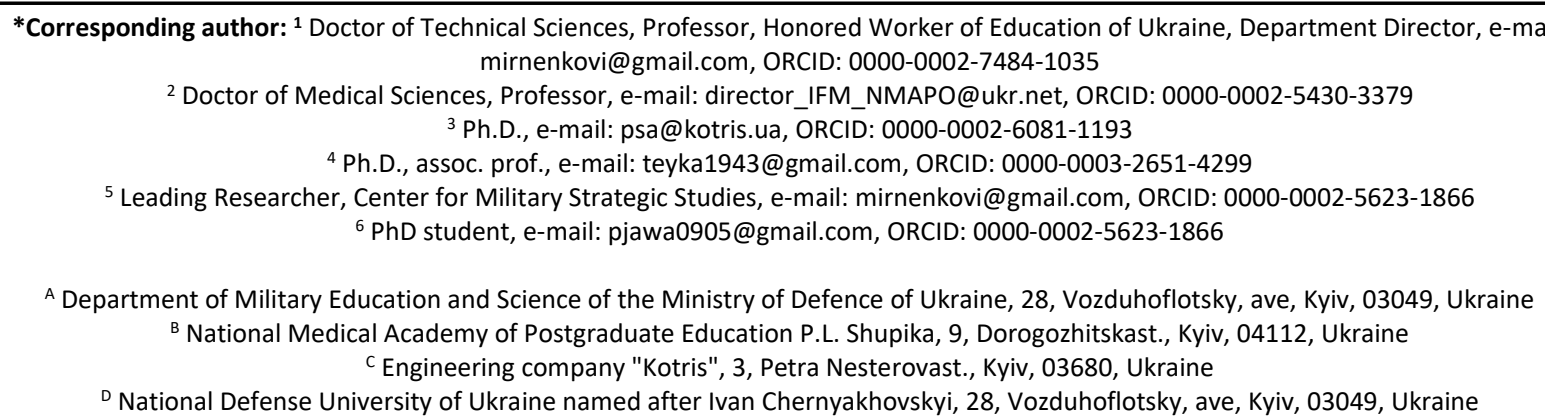

\begin{abstract}
The article establishes the dependence of the efficiency factor of servicemen on the level of quality of diagnosis in the medical and sanitary part, seeking medical help, the duration of treatment, the intensity of false requests for medical help at certain values of the remaining parameters of the mathematical model. The results of the research are obtained on the condition that the function of time distribution between diseases of servicemen is exponential in nature, and the processes of mathematical modeling are described by a semi-Random Process.
\end{abstract}

Keywords: efficiency, duration of treatment, level of diagnosis, frequency of medical examinations, mathematical model.

\title{
References
}

1. Mirnenko, V., Shekera, O., Pustovoy, S., Yablonsky, P., Butenko, M., \& Piavchuk, O. (2020). Determination of the working capacity coefficient of the servicemen from the parameters of the proposed model. Journal of Scientific Papers "Social Development and Security», 10(6), $19-28$. DOI: 10.33445/sds.2020.10.6.3

2. Mirnenko, V., Yablonsky, P., Butenko, M., Lytvynko, S., \& Gutvert, R. (2019). Mathematical model for determining the effectiveness of medical examination of military personnel. Journal of Scientific Papers "Social Development and Security", 9(5), $143 \quad-\quad 157 . \quad$ DOI: $10.33445 /$ sds.2019.9.5.10
3. Formalízovana model' funktsíonuvannya sistemi medichnogo obslugovuvannya naselennya. / Shekera O.G. / Shekera O.G., Yablons'kiy P.M., Shekera O.O., Mel'nik D.V., Kukharchuk K.M., Panasenko M.S. Zdorov'ya suspíl'stva №3-4, 2016, S.130-131

4. Mirnenko, V., Yablonsky, P., Koskov, Y., \& Litvinko, S. (2017). The mathematical model of medical servicing of servicemen with the use semi-Markov stochastic process theory. Journal of Scientific Papers "Social Development and Security», 2(2), 12 - 24. DOI: $10.5281 /$ zenodo.1117937 